Patients who are functionally impaired are more likely to have emotional disorder, to believe in an infectious cause for their illness, to avoid alcohol, and to be members of a patient self help organisation. Prospective studies are required to determine the aetiological importance of these associations.

We thank Penny Hagar and Susan Simkin for handling and scoring the questionnaires, and Oxfordshire Health Authority for financial support.

1 Valdini A, Steinhardt S, Feldman E. Usefulness of a standard battery of laboratory tests in investigating chronic fatigue in adults. Fam Pract 1989;6:286-91.

2 Lane TJ, Matthews DA, Manu P. The low yield of physical examinations and laboratory investigations of patients with chronic fatigue. $\mathrm{Am} \mathcal{J ~ M e d ~} \mathrm{Sci}$ 1990;299:313-8.

3 Sharpe M, Archard LC, Banatvala JE, Borysiewicz LK, Clare AW, David A, et al. A report-chronic fatigue syndrome: guidelines for research. $\mathcal{I} R$ Soc Med 1991;84:118-21.

4 Holmes GP, Kaplan JE, Gantz NM, Komaroff AL, Schonberger LB, Straus SE, et al. Chronic fatigue syndrome: a working case definition. Ann Intern

5 Hickie I, Lloyd A, Wakefield D, Parker G. The psychiatric status of patients with chronic fatigue syndrome. Br f Psychiatry 1990;156:534-40.

6 Behan PO, Behan MH. Postviral fatigue syndrome. Crit Rev Neurobiol 1988;4:157-79.
.

7 Dowsett EG, Ramsay AM, McCartney RA, Bell EJ. Myalgic encephalomyelitis: a persistent enteroviral infection? Postgrad Med f 1991;66:526-30. 8 Manu P, Matthews DA, Lane TJ, Tennen H, Hesselbrock V, Mendola R, et al. Depression among patients with a chief complaint of chronic fatigue. 7 Affective Disord 1991;17:165-72.

9 Kroenke K, Wood DR, Mangelsdorff D, Meier NJ, Powell JB. Chronic fatigue in primary care; prevalence, patient characteristics, and outcome. JAMA 1988;260:929-34

10 Valdini AF, Steinhardt S, Valicenti J, Jaffe A. A one year follow up of fatigued patients. F Fam Pract 1988;26:33-8.

11 Nelson E, Kirk J, McHugo G, Douglass R, Ohler J, Wasson J, et al. Chief complaint fatigue: a longitudinal study from the patient's perspective. Fam Pract Res f 1987;6:175-87.

12 Wessely S, Powell R. Fatigue syndromes: a comparison of chronic "postviral" fatigue with neuromuscular and affective disorder. 7 Neurol Neurosurg Psychiatry 1989;52:940-8

13 Millon C, Salvato F, Blaney N, Morgan R, Mantero-Atienza E, Klimas N, et al. A psychological assessment of chronic fatigue syndrome/chronic Epstein-Barr virus patients. Psychological Health 1989;3:131-41.

14 Wessely S, David A, Butler S, Chalder T. Management of chronic (post-viral) fatigue syndrome. I $R$ Coll Gen Pract 1989;39:26-9.

15 Butler S, Chalder T, Ron $M$, Wessely S. Cognitive behaviour therapy in chronic fatigue syndrome. $\mathcal{F}$ Neurol Neurosurg Psychiatry 1991;54:153-8.

16 Vincent A, Newsom-Davis J. Acetylcholine receptor antibody as a diagnostic test for myasthenia gravis: results in 153 validated cases and 2967 diagnostic assays. F Neurol Neurosurg Psychiatry 1985;48:1246-52.

17 Nixon DF, Parsons AJ, Eglin RP. Routine full blood counts as indicators of $\frac{\mathcal{S}}{}$ acute viral infections. F Clin Pathol 1987;40:673-5.

18 Yousef GE, Bell EJ, Mann GF, Murugesan V, Smith DG, McCartney RA, et al. Chronic enterovirus infection in patients with postviral fatigue syndrome. Lancet $1988 ;$; : $146-50$

19 Zigmond AS, Snaith RP. The hospital anxiety and depression scale. Acta $\overrightarrow{0}$ Psychiatr Scand 1983;67:361-70.

20 Lewis $\mathrm{G}$, Wessely $\mathrm{S}$. Comparison of the general health questionnaire and the $\overrightarrow{\vec{H}}$ hospital anxiety and drepression scale. Brf Psychiatry 1990;157:860-4.

21 McCullough P, Nelder JA. Generalised linear models. 2nd ed. London: Chapman and Hall, 1989 .

22 Landay A, Jessop C, Lenette E, Levy J. Chronic fatigue syndrome: clinical condition associated with immune activation. Lancet 1991;338:701-12.

23 Wells KB, Stewart A, Hays RD, Burnham A, Rogers W, Daniels M, et al. The of functioning and well being of depressed patients. FAMA 1989;262:914-9. 24 Sharpe M. Psychiatric management of PVFS. Br Med Bull 1991;47:989-1005.

\title{
Association between postpartum thyroid dysfunction and thyroid antibodies and depression
}

Brian Harris, S Othman, J A Davies, G J Weppner, C J Richards, R G Newcombe, J H Lazarus, A B Parkes, R Hall, D I W Phillips

Abstract

Objective-To define the relation between mood and autoimmune thyroid dysfunction during the eight months after delivery.

Design-Double blind comparison of the psychiatric status of women positive and negative for thyroid antibodies. Clinical examination and blood sampling for free triiodothyronine and thyroxine, thyroid stimulating hormone, and thyroid antibody concentrations at four weekly intervals. Psychiatric assessment at six, eight, 12, 20, and 28 weeks post partum.

Setting-Outpatient department of district hospital.

Patients -145 antibody positive women and 229 antibody negative women delivering between August 1987 and December 1989.

Main outcome measures-Thyroid status. Number of cases of mental ill health by the general health questionnaire, research diagnostic criteria, Hamilton 17 item depression scale, hospital anxiety and depression scale, and Edinburgh postnatal depression scale.

Results-Six weeks after delivery the general health questionnaire showed $62(43 \%)$ antibody positive women and $65(28 \%)$ antibody negative women had mental ill health $\left(\chi^{2}=8 \cdot 18, \mathrm{p}<0.005\right)$. Follow up of 110 antibody positive and 132 antibody negative women showed significantly greater depression by research diagnostic criteria in antibody positive women $(47 \%)$ than antibody negative women $(32 \%)$ regardless of thyroid dysfunction. Antibody positive women showed higher mean scores for depression on the Hamilton $(6.01 v 3.89, p=0.0002)$, Edinburgh $(7.45 v 5.92, \mathrm{p}=0.031)$, and hospital depression scales $(4.95 v 3.79, \mathrm{p}=0.003)$.
Conclusion-Depressive symptoms are asso- $\stackrel{\circ}{\circ}$ ciated with positive thyroid antibody status in the $\overrightarrow{\vec{P}}$ postpartum period.

\section{Introduction}

Transient postpartum thyroid dysfunction asso-s ciated with autoimmune thyroiditis was first reported. in 1976 when Amino et al described six cases in women presenting three to four months after delivery" with signs of mild hypothyroidism. ${ }^{1}$ The symptoms included swelling of the neck, cold extremities, and weight gain. Profiles of serum thyroid hormone concentrations showed the women to have hypo- $N$ thyroidism accompanied by raised titres of thyroid $>$

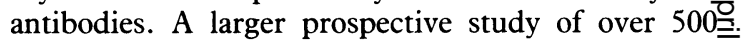
women presenting for delivery showed the commonestr clinical conditions to be mild hypothyroidism, hyper-N thyroidism, and occasionally hyperthyroidism fol-o lowed by hypothyroidism. ${ }^{2}$ Other studies havę confirmed this, ${ }^{3-6}$ and since thyroid disorders are associated with mood disorders, ${ }^{7-10}$ transient thyroid@ dysfunction could possibly be associated with post 7 natal depression.

Postnatal depression occurs in $10 \%$ to $20 \%$ of women in the postpartum year. ${ }^{11-14}$ Although there is over-疋 whelming evidence that factors such as marital disharmony, lack of a confiding relationship, previous psychiatric illness, housing problems, and other socioeconomic problems are strongly associated,,$^{12}$ as subgroup of women may have a hormonal basis forô their depression. ${ }^{12}$ is Anecdotal support for this has been provided by the finding that the mood of some women with post partum thyroid dysfunction mimics that of "depressive psychosis." Hayslip et al found that women positive for thyroid antibodies 
with thyroid dysfunction reported more depressive symptoms than euthyroid antibody positive women.' In a controlled study of 147 women at six weeks post partum, 65 of whom were positive for thyroid antibodies, a weak but significant association of depression with thyroid dysfunction was reported. ${ }^{16}$ However, most cases of postpartum thyroid dysfunction occur later than the puerperium, ${ }^{461718}$ suggesting that any association with depressed mood would also be detectable at that time. We assessed antibody positive and antibody negative women for affective disorder over the first eight months post partum.

\section{Subjects and methods}

This study received ethical approval from Mid Glamorgan Health Authority. Women presenting sequentially at 16 weeks' gestation at the Caerphilly and District Miners' Hospital were admitted to the study after giving informed consent. They came from a working class population and mainly belonged to social groups III-V. We took blood samples to determine thyroid antibody status antenatally (at 16 weeks) and postnatally (within a day of delivery). A thyroid microsomal antibody concentration of $525 \mathrm{U} / \mathrm{ml}$ or above at either time point was taken to indicate positive thyroid antibody status. Women were excluded from the study if they had a known thyroid disorder, had a stillbirth, or lived in geographically remote areas.

We screened 1248 women. All 145 women positive for thyroid antibody were recruited into the study. We aimed at recruiting two antibody negative women matched for age (within five years) for each positive woman. This ensured that at least one control woman completed the study. A total of 229 of the remaining 1103 eligible antibody negative women were included in the study. Although the women were not specifically matched for parity, the aim was to achieve no significant difference between the two groups in this respect.

\section{THYROID FUNCTION}

Women were seen at four weekly intervals for eight months after delivery for thyroid assessment, and on each occasion blood was taken to measure free triiodothyronine and thyroxine, thyroid stimulating hormone, and thyroid antibody concentrations. Patients who failed to attend were visited at home by a research nurse, who took a blood sample.

\section{PSYCHIATRIC SURVEY}

At six to eight weeks post partum the 30 item general health questionnaire ${ }^{19}$ was administered to all women. We used a cut off point of 7 -that is, omitting the scores for the two questions unsuitable for women with a new baby "restless nights" and "getting out of the house" as validated by Nott. ${ }^{20}$

To obtain roughly equal numbers of women with positive and negative thyroid antibody status 110 antibody positive and 132 antibody negative women (age matched) were assessed at eight, 12, 20, and 28 weeks by a psychiatrist (BH, JAD, or GJW). The women were sampled so that about $50 \%$ in each group had a positive score on the general health questionnaire for maximum informativeness. When women did not attend for their assessments they were contacted by telephone and a home visit was arranged. If a home visit was not possible, self completion questionnaires were sent to the women with a stamped addressed envelope for return. The psychiatrists were not aware of the thyroid status of the women. Women were not specifically informed of their thyroid antibody status by any of the investigators. If they were aware of their status they were requested not to disclose this information to the psychiatrists.

After a short unstructured probe concerning the woman's current mental health each interview proceeded with an assessment according to research diagnostic criteria for depression (definite major, probable major, definite minor, probable minor). ${ }^{21}$ After this the woman was rated on the Hamilton 17 item scale for depression (cut off score $\geqslant 15$ )..$^{22}$ The interview at eight weeks post partum was concluded by completing the life events schedule devised by Paykel et al which covered the previous 12 months. ${ }^{23}$ Women also completed the following self rating scales: the Edinburgh postnatal depression scale (cut off score $\geqslant 13)^{24}$ and the hospital anxiety and depression scales $(\geqslant 11) .25$

During the puerperium and subsequent months special care is needed in assessing depression because of many confusing factors. Sleeplessness, for example, could be due to depression or to the demands of a new baby. The research diagnostic criteria were used therefore as the standard and the other questionnaires to rate the severity of the depression. The general health questionnaire, for example, is highly sensitive and identifies all categories of research diagnostic criteria depression. The Hamilton rating scale contains within it questions which are specific to biological changes such as severe weight loss. A further aim therefore was to compare the abilities of the various questionnaires to identify the categories of research diagnostic criteria depression.

\section{LABORATORY METHODS}

After separation serum samples were stored at $-20^{\circ} \mathrm{C}$ until analysed. Free triiodothyronine and free thyroxine concentrations were measured by using radiolabelled analogues (Amerlex $M$, Amersham International, Amersham). The coefficients of variation for free triiodothyronine were $3 \cdot 2 \%$ and $5 \cdot 6 \%$ at $10 \cdot 8$ and $22.9 \mathrm{pmol} / \mathrm{l}$ respectively. Between batch precision of free thyroxine assays was $4.5 \%$ at $12.7 \mathrm{pmol} / \mathrm{l}$ and $5 \cdot 8 \%$ at $42 \mathrm{pmol} / \mathrm{l}$. Thyroid stimulating hormone was measured by an in house radioimmunoassay. ${ }^{26}$ The precision of the assay was $10 \%$ over the range 0.5 to $30 \mathrm{mU} / \mathrm{l}$ of the hormone. The limit of detection was $0.1 \mathrm{mU} / \mathrm{l}$. Results were log transformed.

Autoantibodies were measured with an enzyme linked immunosorbent assay (ELISA). ${ }^{27}$ Laboratory normal ranges were used that were based on the values obtained from a group of normal subjects who showed no evidence of thyroid dysfunction. The upper $95 \%$ reference limit of the normative series for thyroglobulin antibody was $250 \mathrm{U} / \mathrm{ml}$ and for microsomal antibody $525 \mathrm{U} / \mathrm{ml}$.

Hyperthyroidism was defined as a raised free triiodothyronine or thyroxine concentration and suppressed thyroid stimulating hormone concentration $(<0.2 \mathrm{mU} / \mathrm{l})$ or raised free triiodothyronine and thyroxine concentrations and normal thyroid stimulating hormone concentration. Hypothyroidism was defined as raised thyroid stimulating hormone and lowered free triiodothyronine or thyroxine concentrations or thyroid stimulating hormone concentration $>10 \mathrm{mU} / \mathrm{l}$ even if free triiodothyronine and thyroxine concentrations were normal. We defined postpartum thyroid dysfunction as the presence of thyroid dysfunction at any time between 0 and 32 weeks after delivery.

\section{STATISTICAL METHODS}

Reference ranges for thyroid hormones were determined by a Gaussian model (log Gaussian for thyroid stimulating hormone). Analysis of variance was used to test time dependence of thyroid hormone concentrations. Statistical evaluation of free triiodothyronine and thyroid stimulating hormone results obtained from subjects who showed no evidence of thyroid disease at any time during the postpartum period showed that there was no significant deviation of the 
values obtained at each time point from the pooled mean values for these hormones (by analysis of variance). Thus a single $95 \%$ reference range was derived for each of these biochemical parameters. However, a significant trend of increasing free thyroxine concentrations in the six months post partum was detected in the data obtained for free thyroxine in antibody negative women with normal thyroid function $(\mathrm{p}<0 \cdot 001)$. For this reason separate $95 \%$ reference ranges were determined at each time point for thyroxine, based on a fitted quadratic model.

We calculated that about 100 antibody positive and 100 antibody negative women needed to be assessed to estimate the proportion of each group showing "any depression" according to research diagnostic criteria within $10 \%$ with a $95 \%$ confidence interval. With the attained sample sizes (110 and 132) a 23\% difference between the percentages in each group with depression is detectable with a power of $95 \%$ at a $5 \%$ level of significance.

The sampling of women for psychiatric assessment was deliberately weighted towards the maximal ascertainment of women with positive results on the general health questionnaire and more limited sampling of those with negative results, particularly of women who were also antibody negative. Consequently analyses evaluating the relation of psychometric scales to antibody status and thyroid dysfunction incorporated weighting to correct for this. These weighted analyses used Mann-Whitney tests and $\chi^{2}$ tests. Estimated means, proportions, and confidence intervals for differences in proportions also incorporated weighting. For example, the crude proportion of antibody negative women with any depression according to research diagnostic criteria was $50 / 126$ or $40 \%$, but only 72 $(57 \%)$ of these women had negative results on the general health questionnaire. The incidence of depression in women with negative results $(13 / 72,18 \%)$ was much lower than that in those with positive results (37/54, 69\%). Accordingly, we estimated that among all 229 antibody negative women, of whom $164(72 \%)$ had negative results on the general health questionnaire, the proportion depressed should be reduced to $32.4 \%$. In the antibody positive group, for whom the degree of underrepresentation of women with negative results on the questionnaire in the group assessed psychiatrically was less extreme, the effect of weighting was less strong: the crude proportion exhibiting depression was $50 \cdot 5 \%$, the corresponding adjusted proportion was $47 \cdot 3 \%$. Full details of the analyses can be obtained from the authors.

The methods used did not explicitly incorporate the individual matching of control(s) to each case because of the complexity of the design. Firstly, the number of controls obtained per case was variable. Secondly, the case and her matched control(s) would not necessarily be in the same subgroup defined by general health questionnaire results. Though age and parity are of some importance as matching factors, their relation to the main factors under study was not judged sufficiently close to make its incorporation in the analysis obligatory; individual matching was used

TABLE I - Weighted mean psychometric scores ${ }^{\star}$ by antibody status and thyroid dysfunction

\begin{tabular}{lcccc}
\hline Rating scale & $\begin{array}{c}\text { Antibody } \\
\text { negative } \\
(\mathrm{n}=132)\end{array}$ & $\begin{array}{c}\text { Antibody positive } \\
(\mathrm{p} \text { value }) \dagger \\
(\mathrm{n}=110)\end{array}$ & $\begin{array}{c}\text { Antibody positive } \\
\text { with thyroid dysfunction } \\
(\mathrm{p} \text { value) } \\
(\mathrm{n}=62)\end{array}$ & $\begin{array}{c}\text { Antibody positive } \\
\text { without thyroid } \\
\text { dysfunction } \\
(\mathrm{n}=48)\end{array}$ \\
\hline Edinburgh & 5.92 & $7 \cdot 45(0.031)$ & $7 \cdot 80(0.015)$ & $7 \cdot 15$ \\
Hamilton & 3.89 & $6.01(0.0002)$ & $6.05(0.00003)$ & 5.91 \\
Hospital anxiety & 5.62 & $6.35(0.114)$ & $6 \cdot 49(0.115)$ & 6.30 \\
Hospital depression & 3.79 & $4.95(0.003)$ & $5 \cdot 15(0.003)$ & 4.77 \\
\hline
\end{tabular}

* Mean of values at four visits adjusted to account for timing and missing values.

tCompared with antibody negative women.

$\ddagger$ Differences between antibody positive women with and without thyroid dysfunction all $p>0.05$. only to produce two reasonably comparable groups.

Input characteristics of case and control groups were compared by Mann-Whitney and $\chi^{2}$ tests as appropriate.

\section{Results}

\section{PATIENT POPULATION}

The 145 women positive for thyroid antibody and 229 negative for antibody did not differ significantly in age (positive women mean 26.6 (range 18-42) years; negative women $25.9(16-40)$ years), parity (median 2 (1-5); 2 (1-9)), marital status, and smoking habits. Similarly, the 110 antibody positive women and the 132 antibody negative women who had further psychiatric assessment did not differ significantly in terms of age $(27 \cdot 5(18-42) ; 26 \cdot 1$ (17-40) years), parity (2 (1-5); $2(1-6))$, marital status, and smoking habits. The numbers of life events occurring in the past 12 months in these two groups were not significantly different (mean $2 \cdot 81 ; 2 \cdot 69$ ). Since assessments began at six weeks post partum the phenomenon of maternity blues (which occurs in the 10 days or so after delivery) was not observed. In addition, during the study no cases of full psychosis were seen.

Failure to carry out an observer rated assessment was not a major problem - for example, for the first full psychiatric interview only six women were not assessed. Women who were not assessed tended to be slightly more depressed on the self rated scales than those who were interviewed, but not significantly so. We carried out about 3500 patient assessments (both medical and psychiatric), of which 500 were home assessments. No difference was found in the proportion of antibody positive and antibody negative women requiring home visits.

\section{THYROID AND PSYCHIATRIC STATUS}

One hundred and ten of the 145 antibody positive women and 132 of the 229 antibody negative women had psychiatric assessment. Sixty two (43\%) of the antibody positive women and $65(28 \%)$ of the antibody negative women scored seven points or higher on the general health questionnaire $\left(\chi^{2}=8 \cdot 18, p<0.005\right)$. Sixty two of the antibody positive women developed episodes of thyroid dysfunction according to the defined criteria: 24 had hyperthyroidism and hypothyroidism, 11 had hyperthyroidism alone, and 27 hypothyroidism alone. None of the antibody negative women developed post partum thyroiditis. Thyroid microsomal antibody concentrations rose significantly over the six months post partum in the antibody positive group. The ranges of antibody concentrations (proportions with values of $525 \mathrm{U} / \mathrm{ml}$ or above) were 100 to $14540 \mathrm{U} / \mathrm{ml}(65 \%)$ at four weeks; 100 to $15620 \mathrm{U} / \mathrm{ml}(70 \%)$ at 12 weeks; and 100 to $16910 \mathrm{U} / \mathrm{ml}(75 \%)$ at 20 weeks. The geometric means were $1112(95 \%$ confidence interval 828 to 1493$) \mathrm{U} / \mathrm{m}$ at four weeks, $2455(1820$ to 3310$) \mathrm{U} / \mathrm{ml}$ at 12 weeks, and 4295 (3410 to 5410$) \mathrm{U} / \mathrm{ml}$ at 20 weeks. The corresponding levels in the antibody negative group were 140 (120 to 161 ), 137 (118 to 159), and 144 (124 to 166) $\mathrm{U} / \mathrm{ml}$.

Table I compares the psychometric scores. Among antibody positive women there were no significan differences in psychometric scores between those who did and those who did not have postpartum thyroid dysfunction. However, both of these groups scored higher on the three scales for depression than did the antibody negative group.

The proportions of women scoring above the cut off points for the various questionnaires were also compared between groups (table II). Although higher proportions of antibody positive women tended to score above the cut off points for each scale this reached 


\begin{tabular}{|c|c|c|c|c|c|}
\hline Rating scale & $\begin{array}{c}\text { Antibody } \\
\text { negative } \\
(\mathrm{n}=132)\end{array}$ & $\begin{array}{c}\text { Antibody } \\
\text { positive } \\
(\mathrm{p} \text { value }) \dagger \\
(\mathrm{n}=110)\end{array}$ & $\begin{array}{l}95 \% \text { Confidence } \\
\text { interval for difference } \\
\text { between antibody } \\
\text { positive and negative } \\
\text { groups }(\%)\end{array}$ & $\begin{array}{c}\text { Antibody positive } \\
\text { with thyroid } \\
\text { dysfunction } \\
\text { (p value) } t \\
(n=62)\end{array}$ & $\begin{array}{c}\text { Antibody } \\
\text { positive without } \\
\text { thyroid } \\
\text { dysfunction } \ddagger \\
(n=48)\end{array}$ \\
\hline \multicolumn{6}{|l|}{ Research diagnostic criteria: } \\
\hline Any depression & 32 & $47(0.009)$ & $3 \cdot 7$ to $26 \cdot 1$ & $55(0.0014)$ & 40 \\
\hline Definite major depression & 11 & $16(0 \cdot 283)$ & $-3 \cdot 7$ to $12 \cdot 7$ & $12(0.946)$ & 21 \\
\hline Edinburgh & 27 & $39(0 \cdot 026)$ & 1.5 to 22.6 & $40(0.040)$ & 38 \\
\hline Hamilton & 13 & $18(0 \cdot 279)$ & -3.9 to 13.4 & $15(0.749)$ & 22 \\
\hline Hospital anxiety & 30 & $34(0.475)$ & $-7 \cdot 0$ to $14 \cdot 9$ & $40(0 \cdot 144)$ & 28 \\
\hline Hospital depression & 17 & $22(0 \cdot 321)$ & -4.4 to 13.5 & $21(0.517)$ & 23 \\
\hline
\end{tabular}

^Positive score on one or more of four assessments.

tCompared with antibody negative women.

$\ddagger$ Differences between antibody positive women with and without thyroid dysfunction all $p>0 \cdot 05$.

significance for only the Edinburgh questionnaire and for research diagnostic criteria for any depressed state. No significant differences emerged between any of the groups in terms of anxiety, whether assessed by mean scores or proportions exhibiting positive results.

Women who developed hypothyroidism with clear symptoms were treated with thyroxine $0.1 \mathrm{mg}$ a day. Treatment was for at least three months or until the end of the trial, whichever was the longer. Women who showed clear evidence of depression, as clinically assessed by a psychiatrist, were given lofepramine $70-140 \mathrm{mg}$ a day. Thirteen women required thyroxine and 20 antidepressant therapy.

The prevalence of positive thyroid antibody status was $11.6 \%$ in the total study population (1248). However, the estimated antibody prevalence in depressed women (any depression on research diagnostic criteria) was significantly higher $(16 \cdot 1 \%, 95 \%$ confidence interval $12 \cdot 1$ to $19 \cdot 8$ ) than that in women without depression $(9 \cdot 3 \%)$.

\section{Discussion}

Our results confirm the finding of an earlier pilot study $^{16}$ and of others ${ }^{235}$ that there is an excess of depressive symptoms and cases of depression overall (but not major depression) in women who are thyroid antibody positive in the eight months after delivery. This was true for all women with positive antibody status regardless of whether they developed thyroid dysfunction according to the defined criteria. The validity of this finding is supported by noting that the psychiatric abnormality was shown by observer as well as self rating scales. In addition, antibody positivity was not related to anxiety (as judged by the hospital anxiety scale) but just to depression. Although some patients may have known their positive antibody or thyroid status no difference in anxiety related symptoms was observed when they were compared with control women. Other confounding variables, including social class, were excluded as far as possible. Furthermore, in subgroups of our patients there were no differences in psychiatric status between different thyroid states.

\section{CAUSE OF ASSOCIATION}

There are several possible explanations for the results. Firstly, the symptoms of general malaise associated with rising antibody concentrations may have been detected as well as actual depressive symptoms. As antibody concentrations rise after delivery cytokines are released during the immune response. These may have an effect on the brain, mediating non-specific behavioural responses such as malaise, fatigue, sleep disturbance, anorexia, apathy, and irritability..$^{28} \mathrm{~A}$ recent review pointed out that emotional disturbance and psychological symptoms may be signs of alterations in central nervous system functions caused by alterations in immune function..$^{29}$ Another possibility relates to the observation that thyroid function in many of the women was changing rapidly-for example, from hyperthyroid to hypothyroid states (11 women in our study). The cause of the change could be autoimmune thyroid follicular cellular destruction, and a blood sample taken at a particular point in time may record normal thyroid hormone concentrations, although they are in a state of flux.

Others have noted depressive symptoms accompanying thyroid dysfunction. ${ }^{23}$ The symptoms are often ascribed to problems such as the demands on the mother and subsequent tiredness. Such depressive symptoms can occur with both hyperthyroid and hypothyroid states. Anxiety symptoms have also been recorded, usually anecdotally. ${ }^{3}$ We attempted to record and measure anxiety symptoms systematically and found no significant excess in antibody positive women or those with thyroid dysfunction.

Depression was usually mild (although incapacitating), and this confirms the finding of Stewart $e t a l^{30}$ that autoimmune thyroid disorders are not associated with more serious psychiatric disease in women admitted to hospital in the postpartum period.

A possible explanation for the overall phenomenon is that it is associated with changes in corticosteroid concentrations. Corticosteroids have an immunosuppressive effect, and during pregnancy cortisol concentration rises to three or four times the normal level. After delivery the concentration returns to normal within two weeks. Although most of the cortisol is bound to cortisol binding globulin, free (biologically active) cortisol concentration also rises, ${ }^{31}$ and this may suppress thyroid autoimmune dysfunction during pregnancy. Falling corticosteroid concentrations after delivery could account for a flare up of thyroid autoimmunity.

\section{IMPORTANCE OF THYROID RELATED DEPRESSION}

About $12 \%$ of childbearing women are positive for thyroid antibodies ${ }^{32}$ Half of these will develop features of a depressive syndrome-that is, $6 \%$ of the total population. However, a third of this $6 \%$ (that is, $2 \%$ ) would have developed depression regardless of thyroid status (table II), leaving 4\% with depression with a probable basis in autoimmune thyroid disease.

The postpartum mood disorder is an organic mood syndrome $\mathrm{e}^{33-35}$-that is, a specific organic factor is aetiologically related to the mood disturbance ${ }^{36}$ and is responsible for a small subgroup within the total number of women developing a depressive disorder in the postpartum year, the distribution of which is known to be skewed. ${ }^{37} 38$ Treatment would be expected to resolve the symptoms of mood disorder. ${ }^{39}$ t0

We thank Amersham International, the Welsh scheme for health and social research, Mid Glamorgan Health Authority, Dr R John, Sisters B McCulloch and P Breay, L Taylor, $\mathrm{C}$ Morrison, and the patients for their help and cooperation. 
I Amino N, Miyai K, Onishi T, Hashimoto T, Arai K, Ishibashi K, et el. Transient hypothyroidism after delivery in autoimmune thyroiditis. f Clin Endocrinol Metab 1976;42:296-301.

2 Amino N, Mori $\mathrm{H}$, Iwatani $\mathrm{Y}$, Tanizawa $\mathrm{O}$, Kawashima $M$, Tsuge I, et al. High prevalence of transient postpartum thyrotoxicosis and hypothyroidism. New Engl F Med 1982;306:849-52.

3 Jansson R, Bernander S, Karlsson A, Levin K, Nilson G. Autoimmune thyroid dysfunction in the post partum period. $\mathcal{F}$ Clin Endocrinol Metab 1984;58:681-7.

4 Fung HYM, Kologlu M, Collison K, John R, Richards CJ, Hall R. Postpartum thyroid dysfunction in Mid-Glamorgan. BMf 1988;296:241-4.

5 Hayslip CC, Fein HG, O'Donnell VM, Friedman DS, Klein TA, Smallridge $\mathrm{RC}$. The value of serum antimicrosomal antibody testing in screening for symptomatic post partum thyroid dysfunction. Am $\mathcal{J}$ Obstet Gynecol 1988;159:203-9.

6 Amino $\mathrm{N}$, Miyai $\mathrm{K}$. Post partum autoimmune endocrine syndromes. In: Autonmmune endocrine disease. New York: John Wiley, 1983:247.

7 Thomas FB, Mazzaferri EL, Skillman TG. Apathetic thyrotoxicosis: a distinctive clinical and laboratory entity. Ann Intern Med 1970;72:679-85.

8 Van Uitert RL, Russakoff LM. Hyperthyroid chorea mimicking psychiatric disease. Am f Psychiatry 1979;136:1208-10.

9 Folks DG. Organic affective disorder and underlying thyrotoxicosis. Psychosomatics 1984;25:243-9.

10 Nemeroff CN, Simon JS, Haggerty JJ, Evans DL. Antithyroid antibodies in depressed patients. Am $\mathcal{F}$ Psychiatry 1985;142:840-3.

1 Kumar R, Robson KM. A prospective study of emotional disorders in childbearing women. $\mathrm{Br} \mathcal{f}$ Psychiatry 1984;144:35-47.

12 Paykel ES, Emms EM, Fletcher J, Rassaby ES. Life events and social support in puerperal depression. $B r f$ Psychiatry 1980;136:339-46.

13 Watson JP, Elliott SA, Rugg AJ, Brough DI. Psychiatric disorder in pregnancy and the first postnatal year. Brf Psychiarry 1984:144:453-62.

4 Cox JL, Connor Y, Kendell RE. Prospective study of the psychiatric disorders of childbirth. Br f Psychiatry 1982;140:111-7.

15 Harris B, Johns S, Fung H, Thomas R, Walker R, Read G, et al. The hormon environment of post natal depression. Br f Psychiatry 1989;154:660-7.

16 Harris B, Fung H, Johns S, Kologlu M, Bhatti R, McGregor AM, et al. Transient post partum thyroid dysfunction and post natal depression. f Affective Disord 1989;17:243-9.

17 Goldman JM. Post partum thyroid dysfunction. Arch Intern Med 1986;146: 1296-9.

18 Jansson R, Dahlberg PA, Winsa B, Meirik O, Safwenberg J, Karlsson A. The post partum period constitutes an important risk for the development of clinical Graves disease in young women. Acta Endocrinologica 1987;116: 321-5.

9 Goldberg DP. The detection of psychiatric illness by questionnaire. Oxford: Oxford University Press, 1972. (Maudsley monographs 21.)

20 Nott PN. Psychiatric illness following childbirth in Southampton: a case register study. Psychol Med 1982;12:557-61.

21 Spitzer RL, Endicott J, Robins E. Research diagnostic criteria: rationale and reliability. Arch Gen Psychiatry 1978;36:773-82.
22 Hamilton $M$. Development of a rating scale for primary depressive illness. Br 7 Soc Clin Psychol 1962:66:278-96.

23 Paykel ES, Prusoff BA, Uhlenhuth EH. Scaling of life events. Arch Gen Psychiatry 1971;25:340-7.

$24 \operatorname{Cox}$ JL, Holden JM, Sagovsky R. Detection of postnatal depression: development of the 10-item Edinburgh postnatal depression scale. Br F Psychiatry 1987;150:782-6.

25 Zigmund AS, Snaith RP. The hospital anxiety and depression scale. Acta Psychiatrica Scand 1983;67:361-70.

26 John R, Jones MK. An immunoradiometric assay for human thyrotropin. Clin Chem 1984;30:1396-8.

27 Groves CJ, Howells RD, Williams S, Darke C, Parkes AB. Primary standardisation for the ELISA of serum thyroperoxidase and thyroglobuli antibodies and their prevalence in a normal Welsh population. f Clin Lab Immunol 1990;32:147-51.

28 Dantzer $R$, Kelley KW. Stress and immunity: an integrated view of Delationsips between the brain and the immune system. Life Sciences 1989;44:1995-2008.

29 Stein M, Miller AH, Trestman RL. Depression, the immune system, and health and illness. Arch Gen Psychiatry 1991:48:171-8.

30 Stewart DE, Addison AM, Robinson GE, Joffe R, Burrow GN, Olmsted MP. Thyroid function in psychosis following childbirth. Am $\mathcal{f}$ Psychiatry 1988; 145:1579-81

31 Scott EM, McGarrigle HHG, Lachelin GCL. The increase in plasma and saliv cortisol levels in pregnancy is not due to increase in corticosteroid bindin globulin levels. f Clin Endocrinol Metab 1990;71:639-44.

32 Prentice LM, Phillips DIW, Sarsero D, Beever K, McLachlan SM, Smith BR. Geographical distribution of subclinical thyroid disease in Britain: a study using highly sensitive direct assays for autoantibodies to thyroglobulin and thyroid peroxidase. Acta Endocrinologica 1990;123:493-8.

33 Young LD. Organic affective disorder associated with thyrotoxicosis. Psychosomatics 1984;25:490-2.

34 Mckenzie TB, Popkin MK. Organic anxiety syndrome. Am 3 Psychiatry $1983 ; 140: 342-4$

35 Lipowski ZJ. A new look at organic brain syndrome. Am $\mathcal{f}$ Psychiatry $1980 ; 137: 674-8$

36 American Psychiatric Association. Diagnostic and statistical manual of mental disorders (DSM III R). 3rd ed. Washington, DC: APA, 1987.

37 Pitt B. Depression following childbirth. Hospital Update 1991;17:133-40.

38 Cooper PJ, Campbell EA, Day A, Kennerley H, Bond A. Non-psychotic psychiatric disorder after childbirth: a prospective study of prevalence, incidence, course and nature. Brf Psychiatry 1988;152:799-806.

39 Kathol RG, Turner R, Delahunt J. Depression and anxiety associated with hyperthyroidism: response to antithyroid therapy. Psychosomatics 1986;27: 501-5.

40 Lazarus JH, Othman S, Hall R, Richards CJ. Hypothyroidism. Lance 1990;336:315.

(Accepted 19 May 1992)

\title{
Contamination of skin and clothing of accident and emergency personnel
}

\author{
Patricia Littlechild, Alasdair Macmillan, \\ Maggie M White, David J Steedman
}

Department of Accident and Emergency Medicine, Royal Infirmary of Edinburgh, Edinburgh EH3 9YW

Patricia Littlechild, senior house officer

Alasdair Macmillan, senior house officer

Maggie M White, senior sister David J Steedman, consultant

Correspondence to: Dr Steedman.

BMF 1992;305:156-7
There is a striking contrast between clothing worn by medical staff working in resuscitation rooms of British accident and emergency departments - traditionally white coats over personal clothing - and the theatrestyle suits and gowns worn by resuscitation teams in North American centres. ${ }^{1}$ We do not know how often personal clothing or uniforms worn by accident and emergency personnel are spattered by blood and other body fluids and the protection afforded. There is, however, a definite risk of infection with various transmissible agents during patient contact. A case report of HIV infection in an accident and emergency health care worker after skin contamination with blood from a seropositive patient having cardiopulmonary resuscitation emphasised the need for suitable protective clothing. ${ }^{2}$ We attempted to assess the risk of clothing soilure and skin contamination during the daily work of accident and emergency staff in a busy teaching hospital accident and emergency department.

\section{Methods and results}

During 1-30 November 1991, 7402 patient attendances were recorded. Medical and nursing staff were asked to check their clothing and exposed skin after each patient contact and if there was definite soilure to clothing to check for visible evidence of underlying skin contamination. Two hundred forms were completed on 212 splash incidents.

Although $2 \cdot 2 \%$ of patients $(n=169)$ presenting to the department were treated within the resuscitation room, $36.3 \%$ of splash incidents (77) occurred there. Altogether $16.5 \%$ of splashes (35) occurred in the examination room mainly as a result of wound management $(22.6 \%$ of splashes (48)). A total of $28 \cdot 8 \%$ of splashes $(61)$ occurred during venous or arterial puncture, but contamination was recorded during 20 other procedures ranging from undressing the patient to last offices Some $47 \cdot 6 \%$ of splashes (101) resulted in skin contamination, and $28.7 \%$ of these (29) occurred despite the area being covered by personal clothing or a uniform. Personal clothing was soiled in $41.0 \%$ of incidents (87) and uniforms in $62.3 \%$ (132). A total of $71 \cdot 2 \%$ of splashes (151) were with patients' blood though splashes of vomitus, sputum, saliva, pus, faeces, and urine were documented.

\section{Comment}

The accident and emergency department operates a policy of "universal precautions," ${ }^{3}$ and medical and nursing staff receive guidance in appropriate barrier procedures when contact with blood or other body fluids is anticipated. Despite the appropriate use of gloves, masks, face shields, gowns, and plastic aprons splashes on clothing and skin contamination may occur. Nursing uniforms do not protect the legs or arms, and white coats do not protect against spattering of personal clothing. White coats have been shown to be a potential source of cross infection, especially when worn in accident and emergency departments. ${ }^{4}$ The soilure of personal clothing is both unacceptable and unhygienic. Contamination of skin despite wearing a 